\title{
Penerapan Problem-Based Learning Untuk Meningkatkan Hasil Belajar Murid Pada Pelajaran Ekonomi Kelas X IIS
}

\author{
Ghaisani Intan Martikasari Fajrin \\ Program Studi S1 Pendidikan Ekonomi, Fakultas Ekonomi, Universitas Negeri Surabaya \\ ghaisanifajrin@mhs.unesa.ac.id \\ Mohamad Arief Rafsanjani \\ Program Studi S1 Pendidikan Ekonomi, Fakultas Ekonomi, Univeritas Negeri Surabaya \\ mohamadrafsanjani@unesa.ac.id
}

\begin{abstract}
ABSTRAK
Kegiatan pembelajaran ekonomi di kelas X IIS 2 seringkali berpusat pada guru sehingga murid kurang termotivasi dalam mengikuti KBM dan mengakibatkan kurang memuaskannya prestasi belajar murid. Oleh karenanya diprelukan sebuah solusi untuk mengatasi malasah tersebut. Penelitian ini memiliki intensi sebagai berikut: 1) mengetahui perubahan aktvitas murid selama mengikuti proses pembelajaran dan 2) mengetahui perubahan prestasi belajar murid setelah diajari dengan menggunakan model pembelajaran kooperatif tipe $P B L$ (PBL). Dalam prosesnya, penelitian ini menggunakan jenis penelitian Penelitian Tindakan Kelas (PTK) sebagai rancangan penelitian. Peserta penelitian melibatkan 35 murid kelas X IIS 2 di SMA Negeri 1 Gresik. Data yang diperoleh dari penelitian ini mengungkapkan bahwa penggunakan metode pembelajaran kooperatif tipe $P B L(\mathrm{PBL})$ dapat meningkatkan aktivitas belajar para murid. Hal ini dibuktikan oleh perolehan pengamatan pada periode pertama yang menunjukkan aktivitas belajar murid mencapai skala 2,6 yang tergolong kurang baik, menjadi 3,1 yang tergolong baik pada pengamatan periode kedua. Di samping aktivitas belajar murid, prestasi belajar murid juga terbukti mengalami kenaikan. Pada akhir periode penelitian pertama, prestasi belajar murid mendapatkan hasil dengan persentase $60 \%$ dan pada akhir periode penelitian kedua, prestasi belajar murid naik menjadi $88,6 \%$.
\end{abstract}

Kata kunci : Penelitian Tindakan Kelas (PTK), model pembelajaran Problem Bades Learning (PBL), aktivitas murid, hasil belajar murid

\begin{abstract}
Learning activity on Economics subject in Class X IIS 2 has been frequently focused on the teacher as the center thus the pupils were less motivated to participate in the teaching-leaning process so that the pupils' learning achievements were not really satisfying. Therefore, a solution is needed to solve the problem. This study intended to 1) discover the change of pupils' learning activities during the learning process and to 2) discover the change of pupils' learning achievement after being taught using cooperative learning model, problem-based learning (PBL) type. During the process, this study used Classroom Action Research (CAR) as the research design. The participant of this study involved 35 pupils of class X IIS 2 at SMA Negeri 1 Gresik. The data gathered from this study revealed that the use of cooperative learning model, problem-based learning (PBL) type could increase the pupils' learning activities. It was proven by the observation result on the first period that showed the pupils' learning activities reached the scale of 2,6 that could be categorized as less satisfactory, to become 3,1 that could be categorized as satisfactory on the second period. Besides the pupils' learning activities, the pupils' learning achievements were also proven to be improved. At the end of the first period, the pupils' learning achievement resulted in the percentage of $60 \%$, and at the end of the second period, the pupils' learning achievement was improved to the percentage of $88,6 \%$.
\end{abstract}

Keywords: Classroom action research (CAR), problem-based learning (PBL) learning model, students activities, students' learning result. 


\section{PENDAHULUAN}

Pendidikan adalah upaya pokok dan disengaja dalam menciptakan atmosfer belajar dan kegiatan pembelajaran supaya murid secara giat mengembangkan kemampuan pada dirinya sehingga memperoleh ketahanan keagamaan, kontrol diri, karakter, intelek, budi luhur, juga kecakapan yang bermanfaat bagi individu, sekitar, bangsa, dan negara (UU No 20 tahun 2003). Sehubung dengan hal tersebut, pendidikan berperan krusial pada setiap individu dalam meraih target meningkatkan kemampuan pada diri setiap murid; karena dengan individu mempunyai ketahanan keagamaan, kotrol diri, karakter yang baik, intelek, budi luhur, juga kecakapan membuat individu tersebut memiliki tujuan untuk menggapai kesuksesan di masa depan dapat berkontribusi untuk memajukan kecerdasan suatu bangsa.

Pendidikan formal dilakukan pada sekolah yang di dalamnya terdapat tenaga pendidik (guru), murid, dan kurikulum keberhasilan belajar di kelas. Jika standar tersebut belum terpenuhi, dapat disimpulkan bahwa kegiatan pembelajaran belumlah sukses (Trianto, 2009). Saat ini di Indonesia menggunakan kurikulum yang dinamakan kurikulum 2013. Kurikulum ini adalah pengembangan dan perbaikan dari pendahulunya, yaitu kurikulum 2006 (KTSP, Kurikulum Tingkat Satuan Pendidikan). Pada kurikulum 2013, aktivitas belajar-mengajar dilakukan dengan melakukan ancangan ilmiah yang mencakup 5M (memerhatikan, menanya, menghimpun keterangan, menalar/mengasosiasi, dan menyampaikan informasi). Dalam kurikulum 2013 ini, kegiatan pembelajaran disekolah dilakukan menurut Rencana Pelaksanaan Pembelajaran (RPP) dan silabus pembelajaran.

Didalam pelaksanaan pendidikan para murid diharapkan memenuhi standar minimum ketuntasan agar para murid dapat dikatakan sukses mempelajari materi atau bahan yang diajarkan, termasuk pada mata pelajaran ekonomi. Hanya saja di kelas X IIS 2 masih banyak terdapat murid yang belum memenhui KKM yang telah ditentukan oleh pihak sekolah. Berdasarkan hasil wawancara dengan guru pengampu mata pelajaran ekonomi di kelas X IIS 2, permasalahan ini bisa jadi disebabkan oleh murid yang tidak cukup giat pada saat mengikuti KBM (selanjutnya disebut KBM) di kelas. Dalam mengikuti pembelajaran ekonomi para murid cenderung seringkali tidak fokus terhadap kegiatan belejar mengajar, mereka kurang mampu mengutarakan pendapat apabila kurang mengerti tentang materi tersebut,selain itu interaksi di dalam kelas selama ini hampir selalu berpusat pada guru, para murid hanya bergantung pada instruksi atau materi yang diberikan oleh gurunya (membuat murid kurang antusias atau kurang bersemangat).

Sedangakan keberhasilan suatu pembelajaran bisa dicapai melalui beberapa cara, salah satunya menggunakan model pembelajaran yang sesuai. Menilik kembali masalah yang terjadi pada kelas $\mathrm{X}$ IIS 2, Penggunaan metode pembelajaran yang secara aktif melibatkan keikutsertaan para murid sangatlah diperlukan untuk meningktakan aktivitas belajar dan hasil belajar para murid. Fenomena ini sesuai dengan teori yang menyatakan bahwa KBM dinyatakan sukses apabila para murid giat berpartisipasi di dalamnya baik secara jasmani, mental dan sosial (Mulyasa, 2002). Terlebih lagi, dalam meningkatkan peraihan prestasi belajar yang baik di sekolah guru dan murid harus bekerjasama dalam proses pebelajaran untuk menciptakan keaktifan murid di dalam proses belajar mengajar (Hamalik, 2001).

Salah satu cara untuk memperbaiki permasalahan di atas adalah dengan melakukan pengkajian terhadap proses $\mathrm{KBM}$ dengan intensi memperbaiki kemampuan guru dalam mengadakan proses belajar mengajar sehingga mutu proses belajar mengajar menjadi leih baik (Sudikin, dikutip dalam (Pandu, 2013)). Pengkajian semacam ini biasanya disebut sebagai Penelitian Tindakan Kelas( selanjutnya disebut PTK). Dalam penelitian tindakan kelas ini, peneliti menggunakan metode pembelajaran kooperatif tipe PBL sebagai solusi alternatif untuk meningkatkan tingkat aktivitas dan tingkat hasil belajar murid.

PBL adalah suatu model pembelajaran yang menghadapkan murid pada pada suatu kasus dan mengharuskan mereka mengumpulkan informasi yang berguna untuk memecahkan kasus tersebut secara mandiri (Harsono, dalam Suprihatiningrum,2013). Menurut Bellisimo, (dalam Aman, 2016) mengatakan bahwa KBM yang menggunakan model pembelajaran PBL tidak lagi menjadikan guru sebagai pusat komunikasi dalam kelas, melainkan menjadikan siswa sebagai pusat dalam proses KBM. Dari beberapa pendapat di atas dapat didimpulkan bahwa $P B L$ (selanjutnya disebut PBL) menuntut siswa untuk terlibat aktif dalam KBM melalui studi kasus.

Hasil dari sebuah penelitian sebelumnya mengutarakan bahwa penerapan model PBL dapat menambah kemampuan berfikir kritis murid dalam pembelajaran, dan dapat meningkatkan prestasi belajar (Nafiah \& Suyanto, 2014). Hasil penelitian lain mengutarakan dengan penerapan PBL dapat menambah aktivitas mengajar dan aktivitas murid dalam pembelajaran, dan dapat meningkatkan hasil belajar murid dari periode ke 1 terhadap periode yang ke 2 (Ningsih et al., 2018). Penelitian tersebut mendukung hasil penelitian lain sebelumnya yang menyatakan bahwa dengan diterapkannya model PBL membuat murid lebih paham dan berakibat peningkatan hasil belajar (Hajar, 2015).

Kelebihan dalam model pembelajaran $P B L$ adalah sebagai berikut : (1) menumbuhkan keyakinan pada para murid atas kepawaian mereka dalam memecahkan kasus yang nyata, 
membangun otonomi murid di dalam proses kegiatan belajar dengan tujuan meningkatkan pengetahuan, (3) materi yang diajarkan dapat menjadi lebih terfokus dan sesuai dengan tujuan, (4) membentuk aktivitas ilmiah dengan melalui kerja kelompok, (5) membudayakan kegiatan perujukan yang baik pada murid melalui sumber terpercaya, (6) melatih murid untuk dapat mengukur perkembangan belajarnya sendiri, (7) melatih murid untuk dapat berinteraksi secara ilmiah melalui diskusi dan presentasi, (8) menangani kesukaran belajar murid dengan cara tutor sebaya ataupun kerja kelompok (Sohimin, 2013).

Menurut pendapat diatas PBL dalah model pembelajaran yang berdasarkan kepada pemecahan suatu kasus oleh para murid secara mandiri dengan menggunakan informasi dari sumber-sumber yang dipercaya. Sehingga para murid dapat menambah pengetahuan secara mandiri, dan dapat murid berpikir secara kritis tanpa harus selalu bergantung pada instruksi atau penjelasan guru.

Dari pendapat tersebut dapat disimpulkan bahwa PBL adalah model pembelajaran yang diterapkan pada para peserta didik dengan metode mendalami sebuah masalah dan menuntut murid untuk mencari solusi dan menyelesaikan permasalahan tersebut dengan cara peserta didik mencari referensi melalui buku ataupun melalui browsing di internet. Dengan begitu, murid dapat menambah pengetahuan dengan belajar secara mandiri, dan murid dituntut untuk belajar berfikir secara kritis dengan begitu menjadikan murid tidak terfokus hanya dengan materi yang diberikan oleh guru saja. Dengan penerapan model pembelajaran ini menjadikan murid lebih aktif dalam mengikuti proses pembelajaran dan berinteraksi dan saling bertukar pendapat dengan murid yang lain. Dengan begitu diharapkan penerapan model pembelajraran PBL dapat meningkatkan hasil belajar murid. Kesuksesan dari hasil belajar adalah buah dari keterlibatan guru dan murid selama proses pembelajaran. Guru menakar kemampuan murid setelah mengajar, sementara bagi murid hasil belajar adalah sesuatu yang dicapai setelah mengikuti proses belajar mengajar (Dimyati dan Mudjiono, 2006)

Oleh sebab itu untuk menangani masalah di atas peneliti menerapkan metode pembelajaran kooperatif tipe Proble Based Learning (PBL) dengan tujuan untuk: 1. meningkatkan aktivitas belajar murid, 2. meningkatkan hasil belajar murid.

\section{METODE PENELITIAN}

Penelitian ini dilakukan di SMA Negeri 1 Gresik, yang dipilih karena sekolah ini merupakan salah satu Sekolah Menengah Atas yang favorit di Gresik. Subjek penelitian ini melibatkan siswa kelas X IIS 2 di SMA Negeri 1 Gresik yang berjumlah 35 murid.

Rancangan penelitian ini adalah PTK yang bertujuan untuk mengetahui atau menemukan cara atau hal terbaik yang dapat dilakukan di dalam kelas dalam rangka memajukan pembelajaran murid (Mettetal, 2001). Rancangan penelitian ini melibatkan 4 (empat) kegiatan berupa perencanaan (planning), pelaksanaan (acting), pengamatan (observing), dan refleksi (reflecting) yang terangkum dalam sebuah periode yang alurnya dapat diilustrasikan dalam diagram berikut:

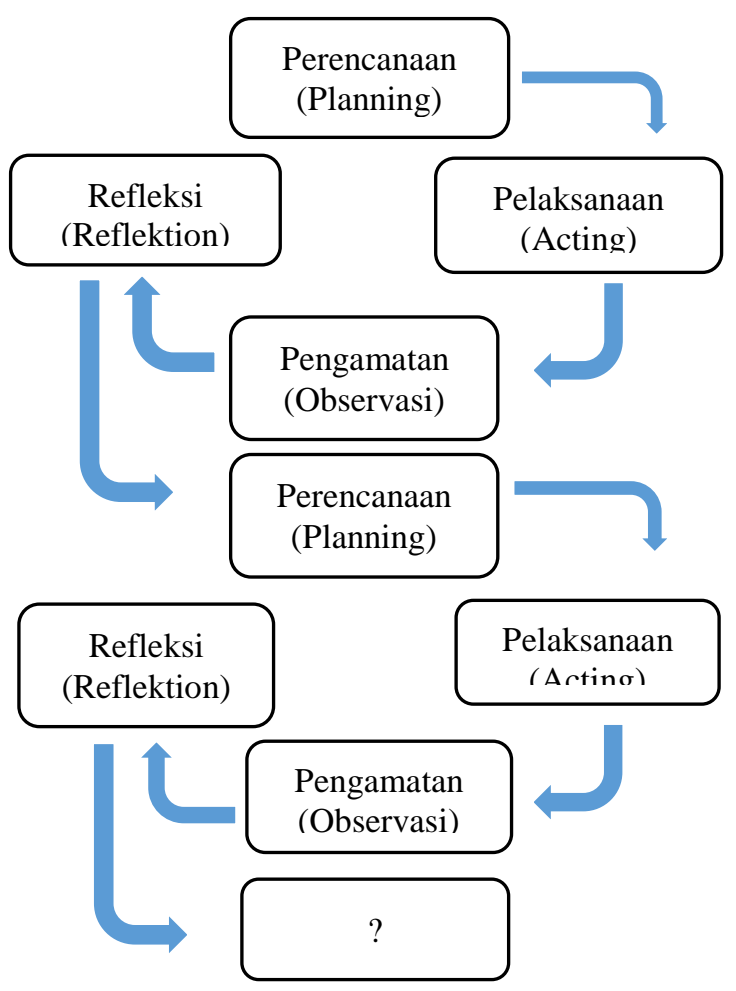

Sumber : (Arikunto \& et al., 2014)

Penelitian ini memerlukan 3 (tiga) periode hingga dampak dari pemakaian model pembelajaran kooperatif tipe PBL ini dinyatakan sukses. Seiring berjalannya rancangan penelitian ini, peneliti melakukan 3 (tiga) cara untuk memperoleh data yang dibutuhkan, yaitu tes (pre-test \& post-tests) untuk mengetahui kompetensi murid sebelum dan sesudah penelitian, observasi untuk mengetahui aktivitas belajar murid selama penelitian, dan penyebaran angket untuk mengetahui opini murid mengenai model pembelajaran yang digunakan selama penelitian.

Cara untuk mengetahui tingkat keberhasilan dalam penelitian penerapan model pembelajaran kooperatif tipe PBL ini adalah dengan penghitungan menggunakan rumus:

1) Untuk mengetahui hasil peningkatan kegiatan murid dapat dilakukan dengan menggunakan rumus: $X=\frac{\sum X}{N}$,

2) Rumus untuk mengetahui tigkat keberhasilan hasil belajar murid yaitu dengan rumus: 
a) Ketuntasan Individu= $\frac{\text { skor yang diperoleh }}{\text { skor maksimal }} \times 100 \%$, murid akan dikatakan lulus ketika mencapai skor sekurang-kurangnya 78 dari skor tertinggi yaitu 100 , atau dapat mencapai ketuntasan belajar sekurang-kurangnya $80 \%$, b) Ketuntasan Klasikal = $\frac{\sum \text { murid yang tuntas }}{\sum \text { seluruh murid }} \times 100 \%$, suatu kelas dikatakan tuntas belajar ketika mencapai prestasi belajar secara keseluruhan mencapai $85 \%$

3) Rumus untuk menghitung lembar angket yang telah disebarkan kepada muridyaiti dengan rumus:

$$
\mathrm{P}=\frac{f}{N} \times 100 \%
$$

(Arikunto, 2009)

\section{HASIL DAN PEMBAHASAN}

Pada periode pertama yang dilaksanakan dalam penelitian ini, peneliti mengawali penelitian dengan memberikan soal pre-test yang digunakan untuk mengtahui kemampuan awal para murid. Setelahnya, peneliti menerapkan Rencan Pelaksanaan Pembelajaran (RPP) untuk mata pelajaran ekonomi kelas X dengan materi sistem dan alat pembayaran. Seusai pebelajaran selesai, murid diberikan soal post-test 1 untuk mengetahui apakah terjadi peningkatan pada prestasi belajar para murid. Setelahnya peneliti merefleksikan proses belajar mengajar yang telah dilaksanakan sebelumnya begitu juga dengan perolehan prestasi murid. Karena masih banyak murid yang prestasi belajarnya belum memenuhi batas minimal kelulusan yang ditetapkan sekolah, maka peneliti perlu untuk melakukan kegiatan yang sama kembali sebagai periode ke 2.

Data yang diperoleh dari penelitian ini berupa nilai kegiatan murid selama penelitian berlangsung, prosentase pencapaian murid sebelum penelitian dan setiap akhir periode penelitian, serta opini para murid mengenai model pembelajaran kooperatif tipe PBL.

\section{Aktivitas Murid}

Pada periode pertama aktivitas belajar murid masih belum terlalu nampak bersemangat. Para murid masih belum cukup aktif dalam mencari informasi, belum termotivasi untuk melibatkan diri dalam diskusi kelompok, maupun berinteraksi dengan guru. Hal ini nampak dari bagaimana murid enggan untuk langsung berkumpul dengan teman kelompoknya begitu terbentuk. Begitu pula pada saat siswa mengambil kartu study kasus dan membacakannya, siswa kurang bersemangat. Sementara itu pada periode ke dua siswa nampak lebih antusias dan aktif dalam KBM.

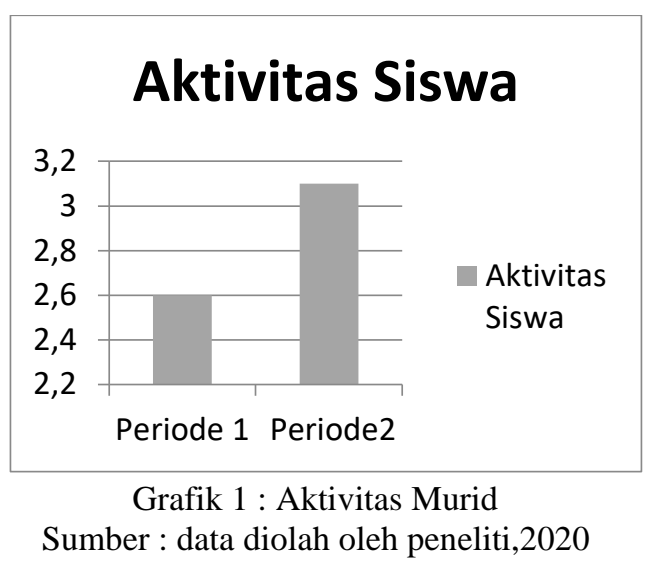

Dari gambar grafik diatas dapat disimpulkan bahwa terjadi peningkatan dalam kegiatan murid selama mengikuti proses pembelajaran kooperatif tipe Problem-based Learning. Dari hasil pengamatan kegiatan murid terjadi peningkatan sebesar 0,5 . Peningkatan ini dilihat dari hasil pengamatan kegiatan murid pada periode ke I sebesar 2,6 yang termasuk dalam kategori yang kurang baik dan pada pengamatan kegiatan murid pada periode ke II sebesar 3,1.

Berdasarkan data di atas dapat dilihat bahwa aktivitas belajar murid mengalami kenaikan setelah diajari menggunkan model pembelajaran $P B L$. Hal ini sesuai dengan pernyataan yang menjelaskan bahwa $P B L$, selain melibatkan studi kasus dalam pelaksanaannya, juga membantu murid untuk mempelajari materi melalui komunikasi dan investigasi secara berkelompok (Tan, 2003).

Meningkatnya aktivitas belajar murid dapat memberikan dampak positif pada KBM. Dengan murid terlibat aktif dalam proses belajar mengajar siswa dapat mengalami dan merasakan sendiri proses untuk mencari, mengolah, dan mempresentasikan informasi sehingga akan membuat mereka mudah memahami materi yang diajarkan. Dalam penerapan model pembelajaran PBL ini seluruh murid berperan aktif dalam diskusi mengenai kasus yang dibahas (Barrett \& Moore, 2011).

Hal ini ini bisa jadi disebabkan oleh rasa percaya diri murid yang cenderung lebih tinggi ketika berkomunikasi dengan teman sebaya dibandingkan saat berkomunikasi dengan guru. Karena apabila berkomunikasi dengan guru terkadang murid merasa takut sehingga komunikasi kurang dapat terjalin dengan baik. Ini dibuktikan oleh penelitian sebelumnya yang mengungapkan bahwa murid ragu atau takut bertanya karena kurang percaya diri, murid kurang memiliki dorongan untuk mengajukan pertanyaannya (Novitasari, 2014).

\section{Hasil Belajar murid}


Dibawah ini dijelaskan dengan menggunkan tabel hasi belajar murid dengan penerapan model pembelajaran kooperatif tipe PBL pada Pre-test, post-test $1 \&$ post-test 2 :

\section{Tabel 1 : Hasil belajar murid secara klasikal}

\begin{tabular}{|c|c|c|c|c|c|}
\hline \multirow{2}{*}{ No } & Tahapan & \multicolumn{2}{|c|}{ Murid Tuntas } & \multicolumn{2}{c|}{ Murd Tidak Tuntas } \\
\cline { 3 - 6 } & & Jumlah & Persettase (90) & Jumlah & Persentase (95) \\
\hline L. & Pre-test & 7 & $20 \%$ & 28 & $80 \%$ \\
\hline 2. & Post-test periode 1 & 21 & $60 \%$ & 14 & $40 \%$ \\
\hline 3. & Post-test periode 2 & 31 & $88,6 \%$ & 4 & $11,4 \%$ \\
\hline
\end{tabular}

Sumber : data diolah oleh peneliti,2020

Dari penjelasan tabel diatas dapat disimpulkan bahwa terjadi peningkatan dalam prestasi belajar murid selama mengikuti proses pembelajaran kooperatif tipe PBL. Peningkatan prestasi murid dilihat dari hasil tes pre-test ke posttest periode I sebesar $40 \%$ dan dari post-test periode I ke post-test periode II sebesar $28,6 \%$. Peningkatan ini dilihat dari hasil tes pre-test yang dilakukan sebelum diterapkan penelitian sebesar $20 \%$ untuk siswa yang tuntas dan $80 \%$ untuk murid tidak tuntas. Pada post-test periode I sebesar $60 \%$ untuk siswa yang tuntas dan $40 \%$ untuk siswa yang tidak tuntas. dan pada saat post-test periode II sebesar $88,6 \%$ untuk murid yang tuntas dan $11,4 \%$ untuk murid yang tidak tuntas. Hasil temuan ini mendukung penelitian sebelumnya yang menunjukkan bahwa penggunaan model pembelajaran PBL dapat meningkatkan prestasi belajar murid (Hajar,N, 2015).

Penjelasan hasil penelitian diatas dapat disimpulkan bahwa dengan menerapkan model pembelajaran kooperatif tipe PBL membuat murid lebih giat dalam mengikuti proses belajar mengajar di kelas karena dengan begitu murid menjadi lebih memahami materi yang diberikan dan berdampak pada peningkatan hasil prestasi belajar murid. Peningkatan hasil belajar dapat dipengaruhi degan adanya penggunaan penerapan model pembelajaran kooperatif tipe PBL, hal ini sesuai dengan teori yang mengungkapkan bahwa pengaplikasian pembelajaran kooperatif menunjang pembelajaran untuk meningkatan pencapaian prestasi para murid, memperluas hubungan antar kelompok, menaikkan pemahaman dalam bidang akademik dan rasa harga diri (Slavin, 2005). Dengan kegiatan belajar secara berkelompok membuat murid akan memperbaiki prestasi belajar murid, karena melalui proses pembahasan dengan teman sebaya menjadikan murid dapat memahami materi dengan lebih baik (Roth, 1994; Brown, 2003: dikutip dalam (Magdalena, 2016)).

\section{Hasil Persentase Respon Murid}

Di bawah ini akan dijelaskan dengan menggunakan tabel dari hasil dari penyebarkan angket pada siswa kelas X IIS 2 dan mendapat jumlah hasil opini mereka sebagai berikut:

Tabel 2: Respon murid

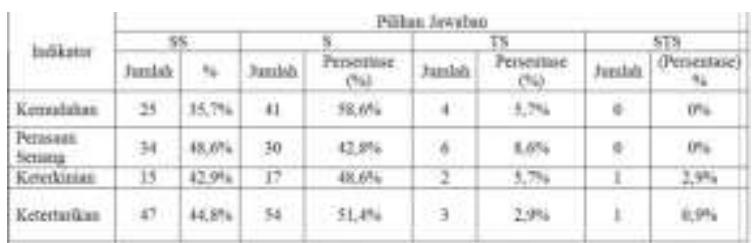

Sumber: data diolah oleh peneliti, 2020

Berdasarkan tabel diatas sebagian besar murid mearasa mudah memahami penerapan skenario model pembelajaran kooperatif tipe $P B L$ dan materi yang diajarkan dengan menggunakan metode pembelajaran tersenbut. Hal ini dapat dibuktikan dengan $66,8 \%$ menyatakan setuju mereka mudah memahaminya. Murid yang merasa senang dengan penerapan model pembelajaran kooperatif tipe PBL dibuktikan sejumlah $70 \%$, murid merasa ini model pembelajaran yang baru diterapkan atau keterkinian dibuktikkan sejumlah $67,2 \%$, dan dibuktikan $70,5 \%$ jumlah murid yang merasa ketertarikan dalam model pembelajaran kooperatif tipe PBL.

\section{KESIMPULAN}

Terjadinya suatu keberhasilan dalam mempraktikkan suatu model pembelajaran kooperatif tipe ProblemBased Leaning (PBL) dapat dibuktikan keberhasilannya lewat fakta bahwa setelah diadakan KBM dengan model pembelajaran tersebut kegiatan belajar murid dan hasil prestasi murid semakin bertambah dari tahapan pembelajaran yang ke I kepada tahapan yang ke II. Meskipun sebenarnya dalam proses pembelajaran ini belum sempurna, dikarenakan terdapat beberapa kendala seperti guru belum cukup dalam memberi bimbingan kepada murid saat kegiatan berdikusi kelompok. Guru kurang cukup memperhatikan waktu yang telah ditetapkan dalam silabus yang sudah ditentukan.

Menurut hasil dari penyebaran angket respon kepada seluruh murid kelas X IIS 2, para murid menyatakan bahwa penggunaan model pembelajarn kooperatif tipe Problem-Based-Learning (PBL) ini layak untuk diterapkan pada proses pembajaran di kelas. Akan tetapi guru wajib memperbaiki ataupun mendisiplikan pengaturan alokasi waktu agar dapat sesuai dengan alokasi waktu yang di buat dalam silabus. guru jyga harus bisa mengatur murid agar lebih bisa kondusif dalam pembelajaran.

\section{SARAN}

Berdasarkan hasil penelitian penerapan model pembelajaran kooperatif tipe PBL (PBL) pada kompetensi dasar mendeskripsikan bank sentral, sistem pembayaran, dan alat pembayaran maka 
peneliti mengajukan beberapa saran sebagai berikut:

1. Sebelum menggunakan model pembelajaran kooperatif tipe PBL (PBL) hendaknya guru memahami komponen model pembelajaran kooperatif tipe PBL (PBL) dan merencanakan pembelajaran yang akan dilakukan dengan baik sehingga dapat berlangsung sesuai harapan.

2. Guru harus memperhatikan waktu pembelajaran dengan menggunakan model pembelajaran PBL (PBL) dengan baik, agar waktu pembelajaran berjalan efektif.

\section{DAFTAR PUSTAKA}

Aman, K. (2016). PENERAPAN MODEL PBL DALAM PEMBELAJARAN SEJARAH UNTUK MENINGKATKAN MOTIVASI DAN PRESTASI BELAJAR SISWA KELAS XI IPS 1 SMAN 1 BUTAR SULAWESI TENGAH. ISTORIA: Jurnal Pendidikan Dan Ilmu Sejarah. https://doi.org/10.21831/istoria.v12i1.9542

Arikunto, S. (2009). Dasar-Dasar Evaluasi Pendidikan Edisi Revisi. Bumi Aksara.

Arikunto, S., \& et al. (2014). Penelitian Tindakan Kelas. Bumi Aksara.

Barrett, T., \& Moore, S. (2011). New Approaches to $P B L$. Routledge.

Dimyati, Mudjiono, (2006). Belajar dan Pembelajaran. Jakarta: PT. Rineka Cipta.

Hajar, N. (2015). Penerapan Model Pembelajaran PBL Untuk Meningkatkan Hasil Belajar Siswa Kelas X-3 Pada Mata Pelajaran Sosiologi Sma Negeri Kebakkramat Tahun Ajaran 2015/2016. SOSIALITAS; Jurnal Ilmiah Pend. Sos Ant, $7(2)$.

Indonesia, P. R. (2003). Undang Undang Republik Indonesia Nomor 20 Tahun 2003. Sistem Pendidikan Nasional.

Magdalena, R. (2016). Penerapan Model Pembelajaran PBL ( PBL ) serta Pengaruhnya terhadap Hasil Belajar Biologi Siswa SMA Negeri 5 Kelas XI Kota Samarinda Tahun Ajaran 2015. Proceeding Biology Education Conference, 13(1), 299-306.

Mulyasa. (2002). Manajemen Berbasis Sekolah: Konsep, Strategi, dan Implementasi. Remaja Rosdakarya.

Nafiah, Y. N., \& Suyanto, W. (2014). Penerapan model problem-based learning untuk meningkatkan keterampilan berpikir kritis dan hasil belajar siswa. Jurnal Pendidikan Vokasi. https://doi.org/10.21831/jpv.v4i1.2540

Ningsih, P. R., Hidayat, A., \& Kusairi, S. (2018). Penerapan PBL untuk Meningkatkan Kemampuan Berpikir Kritis dan Hasil Belajar
Siswa Kelas III. Jurnal Pendidikan, 3(12), 1587-1593.

https://doi.org/10.17977/jptpp.v3i12.11799

Pandu, L. B. (2013). PENERAPAN MODEL PBL

UNTUK MENINGKATKAN KEAKTIFAN

DAN HASIL BELAJAR SISWA PADA

PELAJARAN KOMPUTER (KK6) DI SMK N 2

WONOSARI YOGYAKARTA. Universitas

Negeri Yogyakarta.

Slavin, R. E. (2005). Cooperative learning: Teori, riset, dan praktik. Nusa Media.

Sohimin, A. (2013). 68 Model Pembelajaran Inovatif dalam Kurikulum 2013. Ar-Ruzz.

Suprihatiningrum. (2013). Strategi Pembelajaran Teori \& Aplikasi. Ar-Ruzz Media

Tan, O.-S. (2003). PBL Innovation. Using Problem to Power Learning in the 21st Century. Cengage Learning Asia Pte. Ltd.

Trianto. (2009). Mendisain Model Pembelajaran Inovatif-Progresif Konsep, Landasan, dan Implementasinya pada Kurikulum Tingkat Satuan Pendidikan (KTSP). Kencana Prenada Media Group. 